\title{
Seismicity pattern in north Sumatra- Great Nicobar region: In search of precursor for the 26 December 2004 earthquake
}

\author{
Sujit Dasgupta, Basab Mukhopadhyay and Auditeya Bhattacharya \\ Geological Survey of India, 27 Jawaharlal Nehru Road, Kolkata 700 016, India.
}

\begin{abstract}
We analyse the seismicity pattern including $b$-value in the north Sumatra-Great Nicobar region from 1976 to 2004 . The analysis suggests that there were a number of significant, intermediate and short-term precursors before the magnitude 7.6 earthquake of 2 November 2002. However, they were not found to be so prominent prior to the magnitude 9.0 earthquake of 26 December 2004 though downward migration of activity and a 50-day short-term quiescence was observed before the event. The various precursors identified include post-seismic and intermediate-term quiescence of 13 and 10 years respectively, between the 1976 (magnitude 6.3) and 2002 earthquakes with two years (1990-1991) of increase in background seismicity; renewed seismicity, downward migration of seismic activity and foreshocks in 2002, just before the mainshock. Spatial variation in $b$-value with time indicates precursory changes in the form of high $b$-value zone near the epicenter preceding the mainshocks of 2004 and 2002 and temporal rise in $b$-value in the epicentral area before the 2002 earthquake.
\end{abstract}

\section{Introduction}

An earthquake of magnitude $9.0+$ occurred in the early hours of 26 December 2004 with its epicenter off north Sumatra. This rare, great earthquake is the largest event in the last 40 years, and caused widespread damage in Sumatra and the AndamanNicobar Islands. Earthquake-inflicted damage has however been overshadowed by the unprecedented tsunami which devastated coastal tracts of the Indian Ocean rim countries. A large number of scientific papers and reports have already been published during the last one year on the earthquake and the tsunami of 2004 (e.g., Ammon et al 2005; Banerjee et al 2005; Bilham 2005; Dasgupta et al 2005a, 2005b; Gupta 2005; Lay et al 2005; Stein and Okal 2005; Vigny et al 2005) and have covered mostly seismological and geodetic aspects of the event. We studied the seismicity pattern of the region surrounding the epicenter in order to document the seismic cycle in general and shortlist possible precursors. The objective of this study is to investigate whether there could be any long-term forecast or intermediate-term prediction for this shallow foci interplate mega-thrust earthquake.

The seismotectonic framework of the Andaman Arc System is well known (Eguchi et al 1979; Mukhopadhyay 1984, 1988; Dasgupta and Mukhopadhyay 1993, 1997; Dasgupta et al 2003; Curray 2005 and reference cited therein). The Andaman Arc System together with AndamanNicobar Islands \& backarc Andaman basin in northeast Indian Ocean define a zone of underthrusting of the Indian Plate (lower plate) below the Southeast Asian Plate (upper plate) leading to the formation of the Andaman Island Arc-trench system. The components of the arc system are well exposed on land as fore-arc system in Burma, trench zone (Sunda-Andaman arc) and outer arc with accretionary prism (ophiolites and associated sediments of Andaman, Nicobar

Keywords. Seismicity; seismic quiescence; $b$-value; foreshocks; Sumatra-Great Nicobar region. 


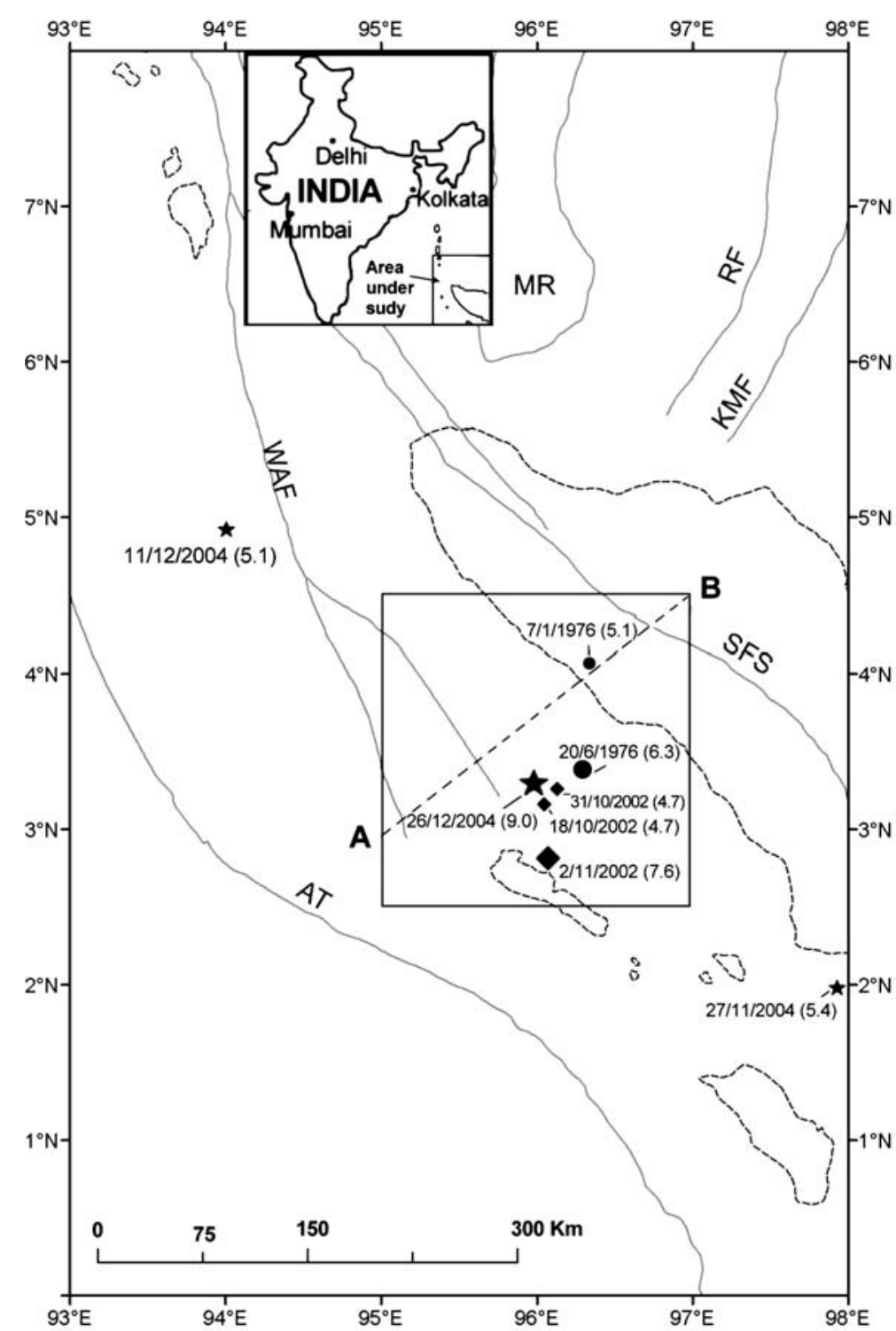

Figure 1(a). Schematic tectonic map of north-Sumatra-Great Nicobar region (after Curray 2005) showing the epicenters of three mainshocks of 1976 (circle), 2002 (rhomb) and 2004 (star) all located within the considered epicentral block (square area). Also plotted one foreshock (small circle) of 1976 earthquake; two foreshocks (small rhomb) of 2002 event (see also table 2) and two pre-shocks (small star) of 2004 great earthquake, that occur well outside the block. The event date and magnitude in $\mathrm{Mb}$ are mentioned in the figure. MR - Mergui Ridge; RF - Ranong Fault; KMF - Khlong Marui Fault; WAF - West Andaman Fault; SFS - Sumatra Fault System; AT - Andaman Trench. A-B section line.

and Nias Islands). The Andaman Sea lying east of Andaman-Nicobar is a back-arc spreading ridge and relates to oblique convergence of the Indian Plate at the Southeast Asian continental margin (Mukhopadhyay 1984; Dasgupta et al 2003; Curray 2005). The earliest tectono-stratigraphic event is represented by accretion of Triassic flysch sediments in late Jurassic time and reported from IndoBurma range; as accretionary collision complex of Cretaceous age in central Indonesia, in Nias Island, west of central Sumatra; as dominant immature sediment and local thrust emplaced ophiolites in Andaman Island. The active tectonic planes in the study area include the Andaman trench, west
Andaman fault, Sumatra Fault System, Ranong Fault and Khlong Marui Fault in the Andaman Sea (figure 1a). For tectonic and seismotectonic set-up of the region, reference is drawn to the papers by Dasgupta et al (2003) and Curray (2005).

\section{Seismicity pattern}

For this study, we utilized the ISC Bulletin data for the period up to December 2001 while for the remaining period NEIC data have been used. The December 2004 earthquake epicenter being located at $3.30 \mathrm{~N}$ : $95.98 \mathrm{E}$ (NEIC) we consider 


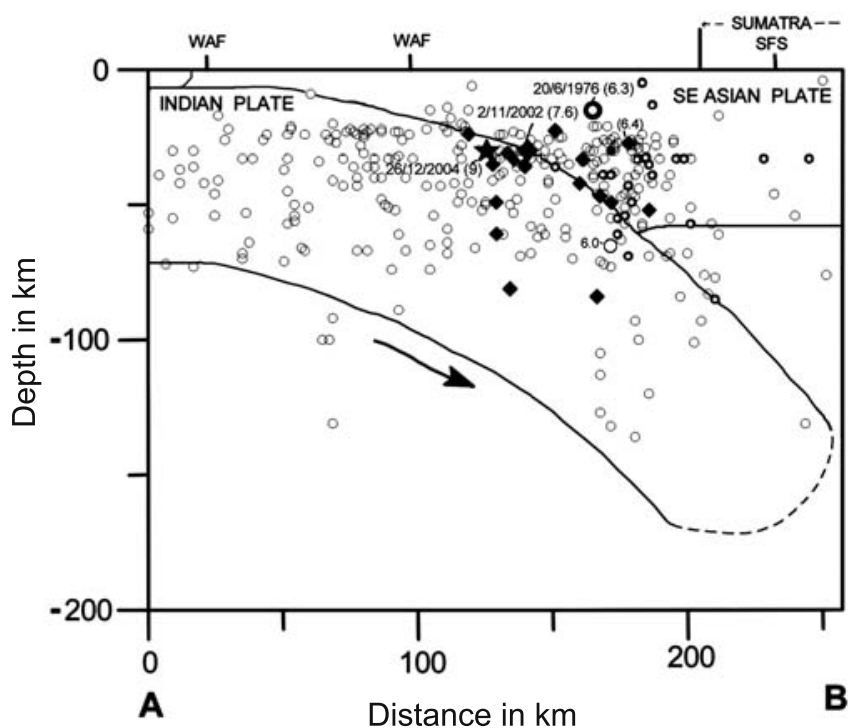

Figure 1(b). A cross section along line A-B of figure $\mathbf{1}(\mathbf{a})$ showing the plate margins in the epicentral block. The 1976 main shock (6.3 M) and aftershocks (solid black ring), 2002 main shock (7.6 M) and aftershock (filled rhombs), 2004 main shock $(9.0 \mathrm{M})$ (solid star), all the earthquake events $(M \geq 4.5)$ in the epicentral block and aftershocks of 2004 events (open circles). Events with $M \geq 6.0$ are labeled.

an area bounded by $0-8 \mathrm{~N}$ : $93-98 \mathrm{E}$ around the north Sumatra-Great Nicobar region for studying the seismicity pattern. From this area we further define an epicentral block $(\approx$ source volume) for the December 2004 earthquake as $2.50 \mathrm{~N}$ to $4.50 \mathrm{~N}$ and $95 \mathrm{E}$ to $97 \mathrm{E}$ and retrieve all the earthquake data. Considering the inadequate sampling of earthquakes below magnitude 4.5 in the region we take data above this threshold for the analysis.

Scholz (1988) has divided the seismic cycle of an active seismic domain into alternate domains of quiescence $\left(\mathrm{Q}_{1}, \mathrm{Q}_{2}\right.$ and $\left.\mathrm{Q}_{3}\right)$ and active seismicity. $\mathrm{Q}_{1}$ is defined as quiescence period between a major shock-aftershock sequence and a further increase in background seismicity. $\mathrm{Q}_{2}$ is defined as a lull period between the previously defined increases in background seismicity and further renewed seismicity. $\mathrm{Q}_{3}$ is defined as a short-term respite of seismicity prior to a major shock-aftershock sequence. The seismicity pattern in this case is evaluated with reference to three major earthquakes of magnitude 6.3 (20.06.1976), 7.6 (2.11.2002) and 9.0 (26.12.2004), and its foreshocks and aftershocks. All these earthquakes occurred along the plate margin of Indian and SE Asian plate (figures 1a and 1b) (for further references consult DeShon et al 2005).

The earthquake data from 1976 to 2004 with $M_{\text {max }}$ for the respective year, for the study area and the epicentral block within it are listed (table 1). One foreshock of magnitude 5.1 that occurred on 07.01.1976 (figure 1a), was identified prior to the main event of June 1976. This earthquake was followed by 47 aftershocks located within the epicentral block (figures 1a, b). After the burst of aftershocks the block witnessed subdued seismicity for 13 years from 1977 to 1989 (table 1), designated as post-seismic quiescence or $\mathrm{Q}_{1}$ of Scholz (1988). This low seismicity rate of 5.38 events/year indicates a state of stress relaxation after a large earthquake. A distinct increase in background seismicity (13.5 events/year) occurred during 19901991 followed by intermediate-term quiescence (5.3 events/year) for another 10 years from 1992 to 2001; this can be designated as $\mathrm{Q}_{2}$ of Scholz (1988). Analysis of data for the year 2002 before the large earthquake (7.6) of 2 November (figure 1a) indicates three clear signatures of short-term precursor. The first is renewed seismicity in the designated epicentral block (table 1); 14 earthquakes occurred in a span of 10 months (table 2). The second is the downward migration of seismic activity (Mogi 1988); 4 earthquakes of focal depth $>70 \mathrm{~km}$ locate to the immediate north of the 2 November shock (table 2) and the third precursor is in the form of two foreshocks (figure 1a) that occur 13 and 2 days before the mainshock of magnitude 7.6 (table 2). Considering the seismicity pattern in the region and signatures discussed, there could have been intermediate-term forecast sometimes during the $\mathrm{Q}_{2}$ phase of quiescence followed by short-term prediction in January-February 2002 from renewed and downward migration of seismic activity. The emerged pattern is however linked to the choice of the epicentral block which is a post facto consideration with very little scope for a priori selection to initiate such study.

Against 47 aftershocks recorded for the mainshock (6.3) of 20 June 1976, only 20 aftershocks were registered for the magnitude 7.6 earthquake of 2 November 2002. A common feature is however rapid restoration to background seismicity; only 6 earthquakes occurred, both in 1977 and 2003 (table 1), following the respective mainshocks. During the years 2003-2004 prior to the mainshock of 26 December 2004, there were only 12 shocks during the period of 21 months (table 2). This could be a short-term quiescence following the magnitude 7.6 earthquake of 2 November 2002 but is not significant to raise any alarm for another impending great event. What appears to be important is the sudden downward migration in seismic activity before the earthquake of 26 December 2004, as also recorded before the magnitude 7.6 earthquake of 2 November 2002; 7 out of 12 events (table 2) originate from deeper levels just before the mega earthquake. This downward migration of seismic activity is followed by a total quiescence of activity for 50 days between 5 November and 25 December 2004. To check whether this quiescence is an artifact of 
Table 1. Basic earthquake statistics in the study area (0-8N: 93-98E) [data source: 1976-2001(ISC); 2002-2004 (NEIC)].

\begin{tabular}{|c|c|c|c|c|c|}
\hline \multirow[b]{2}{*}{ Year } & \multicolumn{2}{|c|}{$\begin{array}{c}\text { Total area } \\
(0-8 \mathrm{~N}: 93-98 \mathrm{E})\end{array}$} & \multicolumn{2}{|c|}{$\begin{array}{l}\text { Epicentral block } \\
(2.5-4.5 \mathrm{~N}: 95-97 \mathrm{E})\end{array}$} & \multirow[t]{2}{*}{$\begin{array}{c}\text { Remarks } \\
\text { (for epicentral block) }\end{array}$} \\
\hline & $\begin{array}{l}\text { Number of events } \\
\quad(\mathrm{Mb} \geq 4.5)\end{array}$ & $M_{\max }$ & $\begin{array}{l}\text { Number of events } \\
\quad(\mathrm{Mb} \geq 4.5)\end{array}$ & $M_{\max }$ & \\
\hline 1976 & 66 & 6.3 & 49 & 6.3 & $\begin{array}{l}\text { Foreshock }(07.01) \\
\text { Mainshock }(20.06) \text { and } \\
47 \text { aftershocks }\end{array}$ \\
\hline 1977 & 10 & 5.8 & 6 & 5.8 & \multirow{13}{*}{$\begin{array}{l}\text { Post seismic quiescence of } \\
13 \text { years: } Q_{1} \text { of Scholz } \\
(1988)\end{array}$} \\
\hline 1978 & 10 & 5.3 & 4 & 5.3 & \\
\hline 1979 & 12 & 6.2 & 7 & 5.0 & \\
\hline 1980 & 11 & 5.5 & 5 & 5.0 & \\
\hline 1981 & 13 & 5.2 & 5 & 5.2 & \\
\hline 1982 & 29 & 5.6 & 5 & 5.5 & \\
\hline 1983 & 31 & 6.5 & 7 & 5.3 & \\
\hline 1984 & 21 & 5.7 & 4 & 4.8 & \\
\hline 1985 & 17 & 5.2 & 5 & 5.0 & \\
\hline 1986 & 18 & 5.8 & 5 & 5.2 & \\
\hline 1987 & 20 & 5.5 & 7 & 5.3 & \\
\hline 1988 & 19 & 5.8 & 5 & 5.1 & \\
\hline 1989 & 27 & 5.8 & 5 & 5.6 & \\
\hline 1990 & 35 & 6.0 & 15 & 6.0 & \multirow{2}{*}{$\begin{array}{l}\text { Increase in background } \\
\text { seismicity; } 13.5 \text { events/year }\end{array}$} \\
\hline 1991 & 34 & 5.9 & 12 & 5.9 & \\
\hline 1992 & 14 & 5.0 & 5 & 4.7 & \multirow{10}{*}{$\begin{array}{l}\text { Intermediate term } \\
\text { quiescence for } 10 \text { years } \\
\mathrm{Q}_{2} \text { of Scholz }(1988) \\
5.30 \text { events/year }\end{array}$} \\
\hline 1993 & 22 & 6.1 & 6 & 5.8 & \\
\hline 1994 & 29 & 5.6 & 9 & 5.6 & \\
\hline 1995 & 17 & 6.0 & 8 & 5.5 & \\
\hline 1996 & 23 & 5.5 & 4 & 5.0 & \\
\hline 1997 & 22 & 5.7 & 6 & 5.7 & \\
\hline 1998 & 16 & 5.5 & 3 & 4.8 & \\
\hline 1999 & 17 & 5.8 & 6 & 5.8 & \\
\hline 2000 & 14 & 5.2 & 3 & 5.0 & \\
\hline 2001 & 19 & 5.6 & 3 & 5.0 & \\
\hline $\begin{array}{l}2002 \text { (up to } \\
01.11 \text { ) }\end{array}$ & 23 & 6.2 & 14 & 5.7 & $\begin{array}{l}\text { Renewed seismicity, } \\
\text { downward migration and } \\
\text { foreshocks (see table 2) }\end{array}$ \\
\hline $\begin{array}{l}2002 \text { (from } \\
02.11)\end{array}$ & 28 & 7.6 & 21 & 7.6 & Mainshock and aftershocks \\
\hline 2003 & 36 & 5.9 & 6 & 5.2 & $\begin{array}{l}\text { i) Return to background } \\
\text { seismicity or quiescence }\end{array}$ \\
\hline $\begin{array}{l}2004 \text { (before } \\
\text { the mainshock) }\end{array}$ & 37 & 6.2 & 7 & 4.9 & $\begin{array}{l}\text { ii) No seismicity in the } \\
\text { epicentral block between } \\
05.11 \text { and } 25.12: \mathrm{Q}_{3} \text { of } \\
\text { Scholz }(1988)\end{array}$ \\
\hline $\begin{array}{l}2004 \text { (from the } \\
\text { mainshock of } \\
26.12 \text { ) }\end{array}$ & 242 & 9.0 & 23 & 9.0 & Mainshock and aftershocks \\
\hline
\end{tabular}

selection of the epicentral block, we scanned all data from the study area to find that one event of magnitude 5.4 occurred on 27 November to the southeast and another event of magnitude 5.1 on 11 December to the northwest, both outside the epicentral block (see figure 1a) and more than
$200 \mathrm{~km}$ on either side from the epicenter of the 26 December 2004 great earthquake. Thus this quiescence is significant and could be designated as $\mathrm{Q}_{3}$ of Scholz (1988) but without any $\mathrm{Q}_{1}$ and $\mathrm{Q}_{2}$ between the earthquakes of November 2002 (7.6) and December 2004 (9.0). Though two precursors, 
Table 2. Seismicity in the epicentral block (2.5-4.5N: 95-97E) from 2002.

\begin{tabular}{|c|c|c|c|c|c|c|c|c|c|c|}
\hline Yr. & Mo. & Da. & Hr. & Mn. & Sec. & Lat. & Long. & $\mathrm{Mb}$ & Depth & Remarks \\
\hline 2002 & 1 & 22 & 20 & 15 & 6 & 3.49 & 95.63 & 5.3 & 33 & \multirow{8}{*}{$\begin{array}{l}\text { Renewed } \\
\text { seismicity: } \\
8 \text { events in } 5 \text { days }\end{array}$} \\
\hline 2002 & 1 & 24 & 15 & 24 & 5 & 3.51 & 95.61 & 5.4 & 33 & \\
\hline 2002 & 1 & 24 & 17 & 52 & 25 & 3.54 & 95.66 & 5.6 & 33 & \\
\hline 2002 & 1 & 24 & 17 & 56 & 21 & 3.52 & 95.66 & 5.2 & 33 & \\
\hline 2002 & 1 & 24 & 18 & 12 & 5 & 3.53 & 95.66 & 5.7 & 33 & \\
\hline 2002 & 1 & 25 & 14 & 5 & 58 & 3.48 & 95.68 & 5.0 & 33 & \\
\hline 2002 & 1 & 26 & 3 & 58 & 32 & 3.26 & 95.32 & 4.5 & 33 & \\
\hline 2002 & 1 & 26 & 17 & 52 & 17 & 3.33 & 95.61 & 4.6 & 33 & \\
\hline 2002 & 2 & 10 & 5 & 21 & 14 & 3.65 & 95.82 & 4.6 & 77 & \multirow{4}{*}{$\begin{array}{l}\text { Downward } \\
\text { migration of } \\
\text { seismic activity }\end{array}$} \\
\hline 2002 & 2 & 11 & 8 & 29 & 24 & 4.35 & 95.87 & 4.6 & 77 & \\
\hline 2002 & 7 & 16 & 3 & 43 & 39 & 3.92 & 95.61 & 4.6 & 100 & \\
\hline 2002 & 10 & 5 & 10 & 6 & 36 & 4.25 & 96.52 & 4.7 & 82 & \\
\hline 2002 & 10 & 18 & 12 & 31 & 24 & 3.20 & 96.03 & 4.7 & 33 & \multirow{2}{*}{ Foreshocks } \\
\hline 2002 & 10 & 31 & 7 & 55 & 58 & 3.27 & 96.07 & 4.7 & 33 & \\
\hline 2002 & 11 & 2 & 1 & 26 & 11 & 2.82 & 96.08 & 7.6 & 30 & Mainshock \\
\hline 2002 & 11 & 2 & 1 & 38 & 20 & 2.67 & 95.90 & 5.2 & 23 & \multirow{21}{*}{ Aftershocks } \\
\hline 2002 & 11 & 2 & 1 & 45 & 35 & 2.64 & 96.25 & 5.2 & 33 & \\
\hline 2002 & 11 & 2 & 1 & 56 & 54 & 2.59 & 95.89 & 5.0 & 33 & \\
\hline 2002 & 11 & 2 & 2 & 56 & 35 & 2.51 & 95.70 & 4.8 & 33 & \\
\hline 2002 & 11 & 2 & 3 & 46 & 53 & 2.71 & 96.12 & 4.7 & 33 & \\
\hline 2002 & 11 & 2 & 3 & 56 & 32 & 2.61 & 96.06 & 4.8 & 33 & \\
\hline 2002 & 11 & 2 & 4 & 19 & 11 & 2.52 & 96.20 & 4.6 & 33 & \\
\hline 2002 & 11 & 2 & 9 & 46 & 47 & 2.95 & 96.39 & 6.4 & 27 & \\
\hline 2002 & 11 & 2 & 14 & 44 & 57 & 2.97 & 96.32 & 4.7 & 33 & \\
\hline 2002 & 11 & 2 & 19 & 58 & 26 & 2.58 & 96.35 & 4.9 & 33 & \\
\hline 2002 & 11 & 3 & 3 & 59 & 42 & 2.77 & 95.96 & 4.7 & 33 & \\
\hline 2002 & 11 & 8 & 4 & 27 & 53 & 2.64 & 95.99 & 4.5 & 33 & \\
\hline 2002 & 11 & 12 & 17 & 46 & 31 & 2.92 & 96.33 & 4.8 & 33 & \\
\hline 2002 & 11 & 13 & 6 & 47 & 48 & 2.68 & 96.17 & 4.7 & 33 & \\
\hline 2002 & 11 & 13 & 15 & 53 & 9 & 3.01 & 96.09 & 5.6 & 39 & \\
\hline 2002 & 11 & 20 & 7 & 43 & 29 & 2.88 & 96.14 & 4.8 & 33 & \\
\hline 2002 & 11 & 27 & 16 & 27 & 12 & 2.85 & 96.11 & 4.7 & 33 & \\
\hline 2002 & 11 & 30 & 4 & 7 & 9 & 2.89 & 96.21 & 5.2 & 33 & \\
\hline 2002 & 12 & 15 & 15 & 28 & 19 & 2.84 & 95.77 & 4.7 & 33 & \\
\hline 2002 & 12 & 27 & 15 & 51 & 26 & 2.69 & 95.94 & 4.9 & 26 & \\
\hline 2003 & 1 & 3 & 8 & 19 & 50 & 2.97 & 96.05 & 4.9 & 33 & \\
\hline 2003 & 2 & 2 & 6 & 17 & 44 & 4.00 & 95.43 & 5.2 & 80 & \multirow{4}{*}{$\begin{array}{l}12 \text { events in } \\
21 \text { months - short- } \\
\text { term post seismic } \\
\text { quiescence (?) }\end{array}$} \\
\hline 2003 & 2 & 2 & 9 & 37 & 27 & 4.11 & 95.53 & 4.7 & 131 & \\
\hline 2003 & 6 & 28 & 7 & 36 & 42 & 2.77 & 95.76 & 5.2 & 33 & \\
\hline 2003 & 7 & 26 & 20 & 59 & 28 & 3.87 & 95.29 & 4.6 & 64 & \\
\hline 2003 & 9 & 15 & 12 & 14 & 33 & 2.59 & 96.07 & 5.1 & 33 & \multirow{5}{*}{$\begin{array}{l}\text { Downward } \\
\text { migration of } \\
\text { seismic activity }\end{array}$} \\
\hline 2004 & 2 & 27 & 12 & 47 & 43 & 2.64 & 95.92 & 4.8 & 15 & \\
\hline 2004 & 3 & 26 & 19 & 50 & 43 & 3.47 & 96.61 & 4.7 & 83 & \\
\hline 2004 & 5 & 13 & 21 & 9 & 12 & 2.81 & 95.30 & 4.7 & 30 & \\
\hline 2004 & 6 & 17 & 13 & 45 & 41 & 3.24 & 96.33 & 4.7 & 132 & \\
\hline 2004 & 7 & 8 & 17 & 41 & 51 & 3.92 & 95.21 & 4.5 & 55 & \multirow{3}{*}{$\begin{array}{l}\text { Quiescence of } 50 \\
\text { days: } Q_{3} \text { of Scholz } \\
\text { (1988) }\end{array}$} \\
\hline 2004 & 9 & 30 & 15 & 25 & 21 & 3.12 & 96.23 & 4.5 & 106 & \\
\hline 2004 & 11 & 4 & 2 & 40 & 22 & 2.72 & 96.30 & 4.9 & 71 & \\
\hline 2004 & 12 & 26 & 00 & 58 & 53.45 & 3.30 & 95.98 & 9.0 & 30 & Mainshock \\
\hline
\end{tabular}



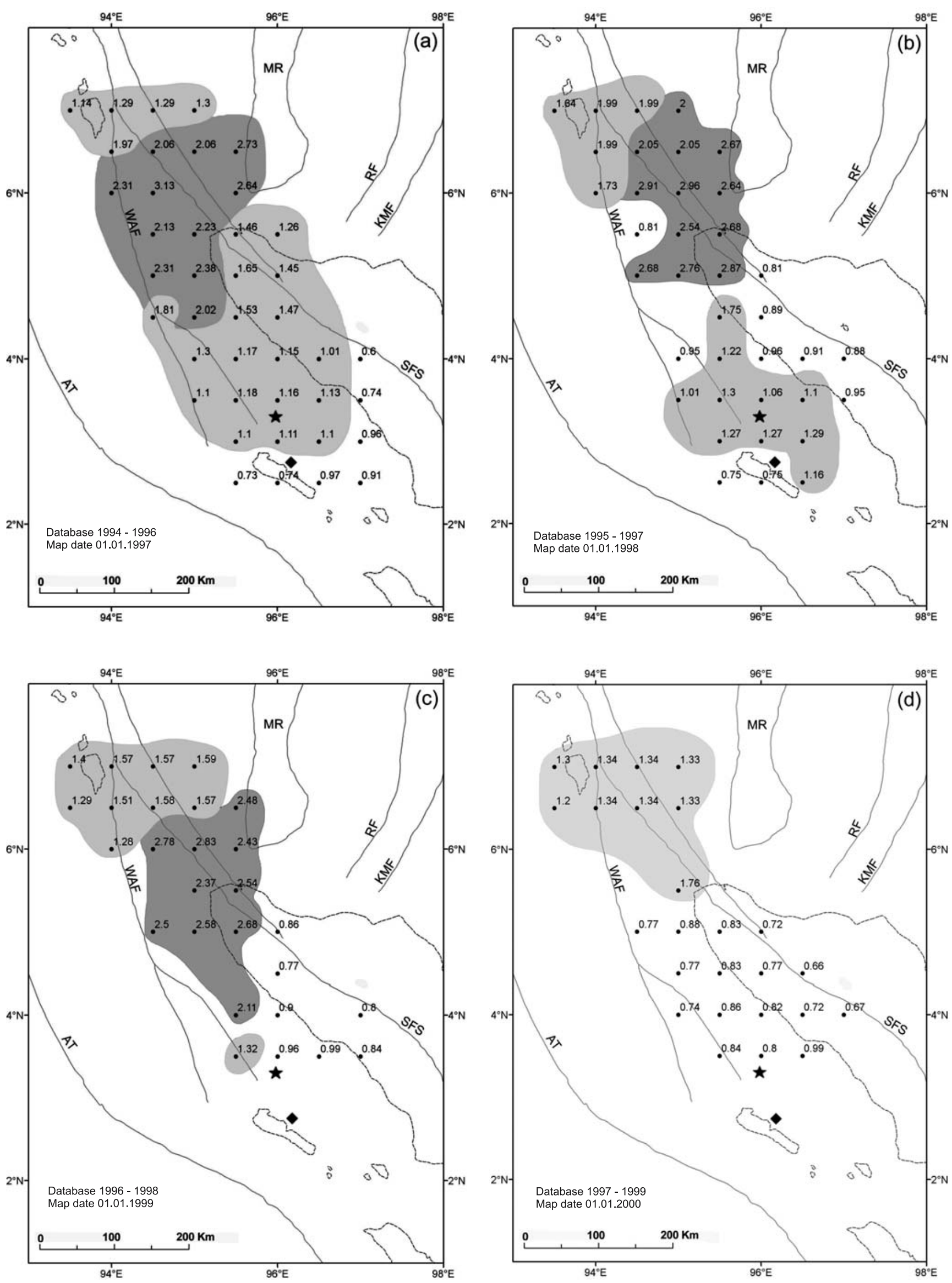

Figure 2. (Continued) 

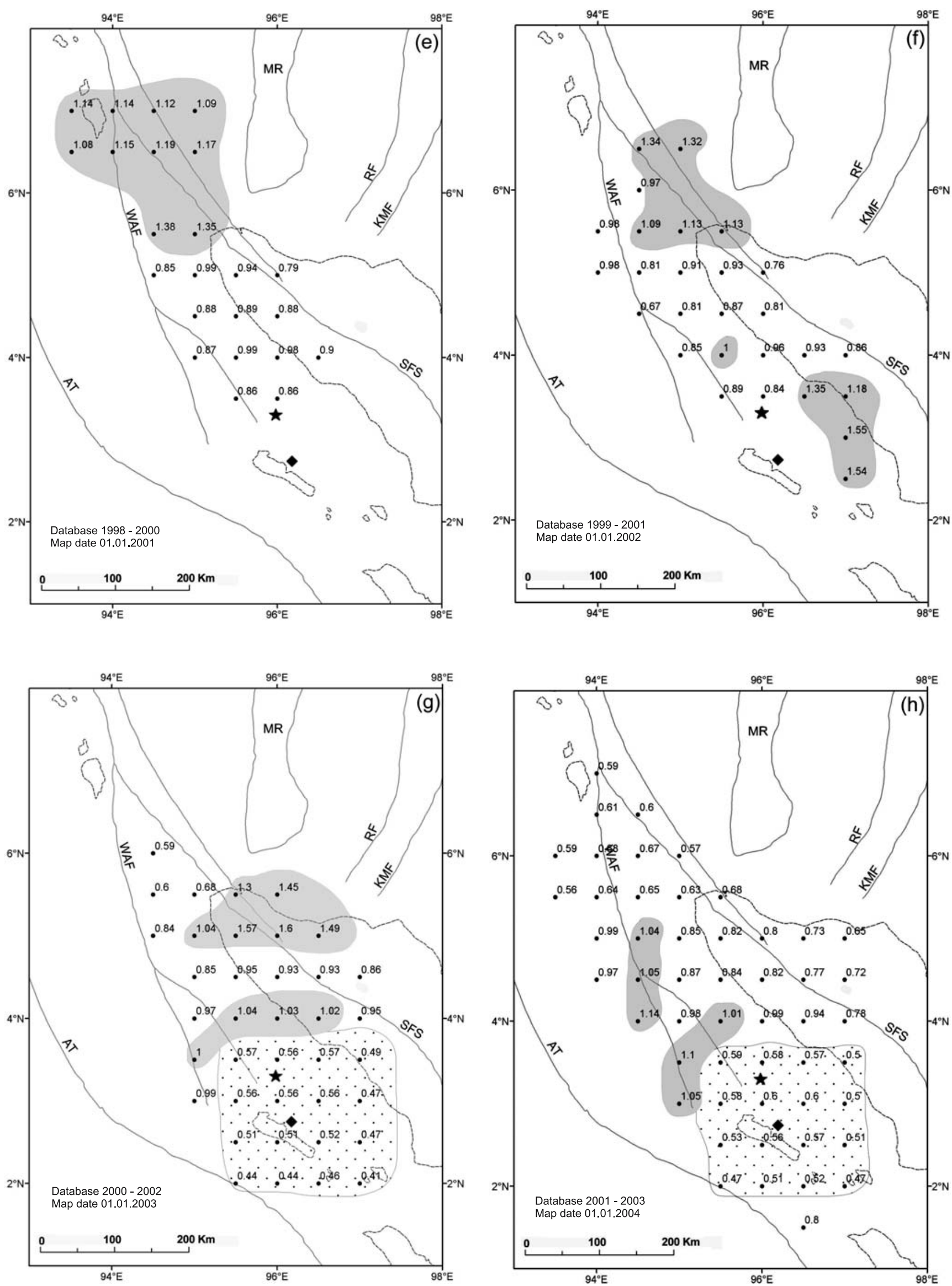

Figure 2. (Continued) 


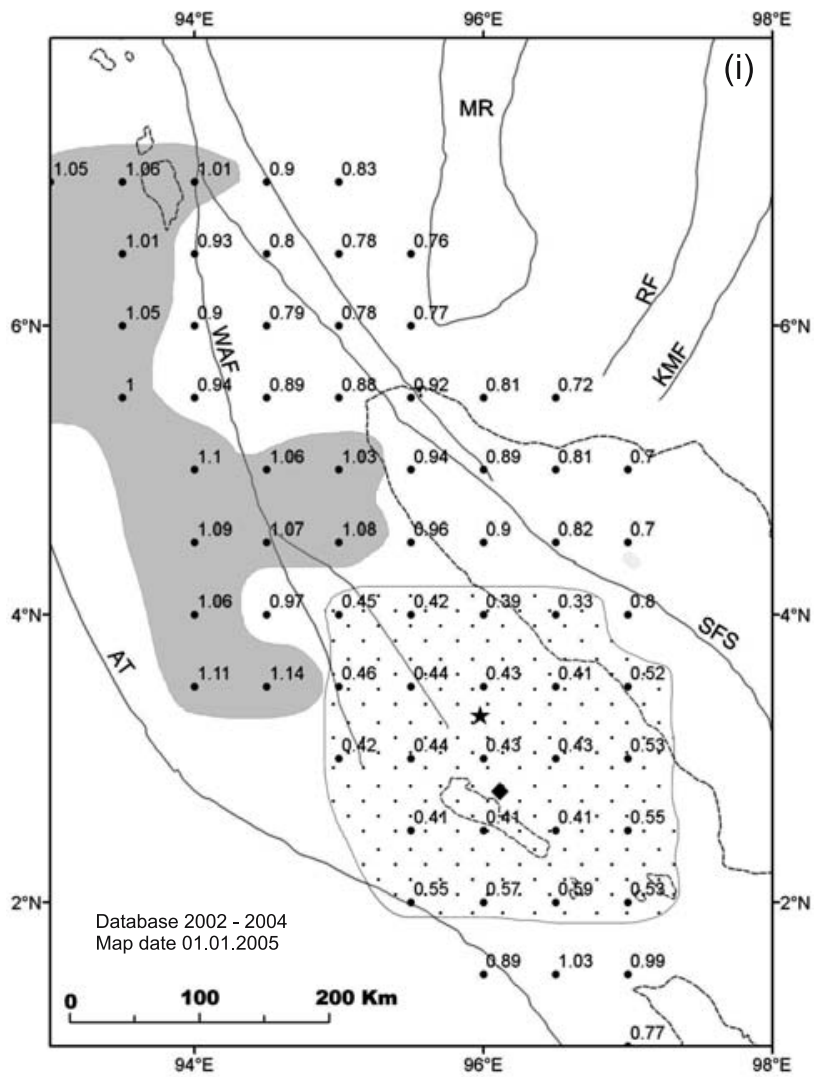

Figure 2. Maps showing spatial variation in $b$-value from time domain 1997 to 2005; b-value map of (a) January 1997 (earthquake database January 1994-December 1996), (b) January 1998 (earthquake database January 1995December 1997), (c) January 1999 (earthquake database January 1996-December 1998), (d) January 2000 (earthquake database January 1997-December 1999), (e) January 2001 (earthquake database January 1998-December 2000), (f) January 2002 (earthquake database January 1999December 2001), (g) January 2003 (earthquake database January 2000-December 2002), (h) January 2004 (earthquake database January 2001-December 2003), (i) January 2005 (earthquake database January 2002-December 2004). $b$-value is calculated for $2^{\circ} \times 2^{\circ}$ blocks plotted at the center of each block. Epicenter for the December 2004 (star) and November 2002 (rhomb) are also shown. Note that the epicenter of 2004 locates close to the high $b$-value zone present up to January 1999.

one, downward migration of seismic activity and two, quiescence of 50 days have been identified, these are not obvious towards forecasting the great earthquake of December 2004. We conclude that while there were a number of precursors to predict the magnitude 7.6 earthquake of November 2002, the December 2004 earthquake could not have been predicted from the study of seismic activity.

\section{3. $b$-value}

We study the $b$-value pattern in the study area to document both temporal and spatial changes in $b$-value and to find whether there is any significant

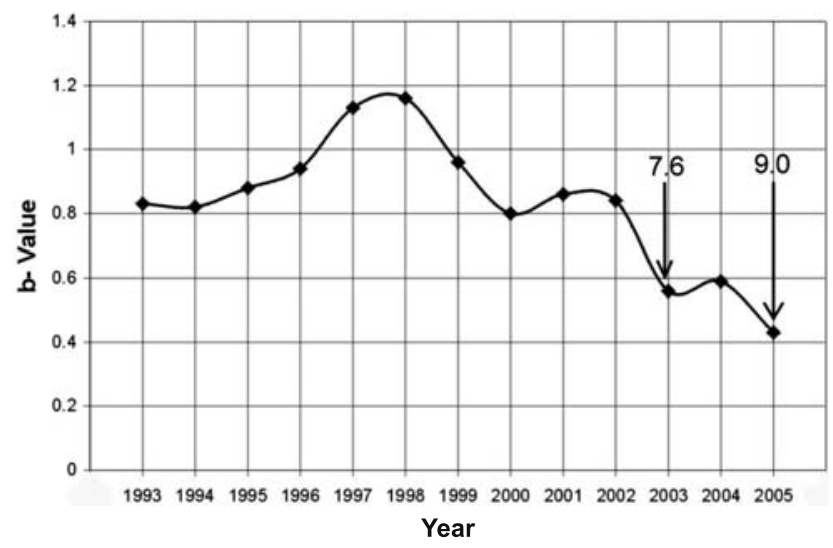

Figure 3. Temporal variation in $b$-value in the epicentral block of 2002 and 2004 earthquakes.

change before the great earthquake of 26 December 2004 and also before the large earthquake of 2 November 2002. For calculating $b$-value we select earthquake data from the study area in $2^{\circ} \times 2^{\circ}$ block with $0.5^{\circ}$ overlapping both along latitude and longitude. The data of three consecutive years with one year overlap since 1990 are used. Thus the $b$ value map generated with data from 1994 to 1996 for the designated blocks is presented with the map date as 01.01.1997 (following Smith 1986), (figures $2 \mathrm{a}-\mathrm{i}$ ). The $b$-values calculated via regression of magnitude $M(\Delta M=0.1)$ against $\Sigma N$ and are plotted at every $2^{\circ} \times 2^{\circ}$ block center when there is a minimum of 10 earthquakes in a block. High $b$ value $(b \geq 2.0)$ and normal $b$-value $(1.0 \leq b<2.0)$ zones depict spatial variation in $b$-value with time and space in respect to the large and great earthquakes of the November 2002 and December 2004 respectively (figures $2 \mathrm{a}-\mathrm{i}$ ).

A zone of high $b$-value locates to the north of the large and great shocks in the maps of 1997, 1998 and 1999 (figure 2a, b and c). Such high values indicate regions of quiescence. The normal $b$-value zone located between the high value and the considered epicenter block has migrated considerably from 1997 to 1999 bringing the high zone closer to the epicenter of 2004 and 2002 earthquakes (figure 2c). Smith (1986) observed that the Cape Campbell earthquake of January 1977 was preceded by and located close to a high $b$-value. In fact, he documented similar high $b$-value patch (proceeding up to 6 years) close to a number of moderately large earthquakes in New Zealand and California and identified it as a precursor anomaly. In the present study area the high $b$-value zone has disappeared from subsequent maps of 2000, 2001 and 2002 (figure $2 \mathrm{~d}-\mathrm{f}$ ) and is mostly replaced by moderately low $b$-value zone $(0.65 \leq b<1.0)$ located to the immediate north of the two mainshocks of 2002 and 2004. Insufficient data ( $<10$ earthquakes), however, is not used to estimate $b$-value in the 
southern part of the study area. Thus from the spatial variation of $b$-value we identify precursory anomaly during January 1997 and January 2002. When data of the 2002 mainshock and aftershocks included for generating $b$-value map as on January 2003 (figure 2g), it indicates that the epicentral region is characterized by a zone of low $b$-value $(0.40<b<0.60)$ along with peripheral normal $b$ value. The picture remains similar for the map of January 2004 (figure 2h) but when the data for 2004 included the resulting map of January 2005 (figure 2i) shows that apart from increase in size of the low $b$-value zone in the epicentral region, a normal $b$-value reappeared similar to the map of January 1997 (figure 2a). There is however no precursory anomaly in the $b$-value maps of January 2003 and 2004 (figures 2g, h).

We further study the temporal variation in $b$-value from January 1993 (data 1990-1992) to January 2005 (data 2002-2004) taking the average $b$-value of two data points located nearest to the earthquakes of November 2002 (3.00N: 96.00E) and December 2004 (3.50N: 96.00E). A clear rise in $b$-value is observed during 1997-1998 (figure 3), which is in the form of intermediate time recovery precursor (see Meredith et al 1990) before the earthquake of November 2002. The temporal variation in $b$-value does not give any clue for the great earthquake in 2004.

\section{Conclusion}

The seismicity pattern from the north SumatraGreat Nicobar region has been studied from 1976, since an earthquake of magnitude 6.3, to 2004 when the great earthquake of magnitude 9.0 occurred. A complete seismic cycle of 25 years with different seismic phases of quiescence (Scholz 1988) and downward migration of seismic activity (Mogi 1988) has been identified from the source region of 20 June 1976 (6.3), 2 November 2002 (7.6) and 26 December 2004 earthquakes. Spatial and temporal variations in $b$-value show that the earthquake of 2 November 2002 was associated with precursors but the mega earthquake of 26 December 2004 has no precursors except downward migration and shortterm quiescence. Earthquake precursors are nonunique and yet to be understood.

\section{References}

Ammon C J, Ji C, Thio $\mathrm{H}$ K, Robinson D, Ni S, Hjorleifsdottir V, Kanamori H, Lay H, Das S, Helmberger D, Ichinose G, Polet J and Wald D 2005 Rupture Process of the 2004 Sumatra-Andaman Earthquake; Science $\mathbf{3 0 8}$ 1133-1139.

Banerjee P, Pollitz F F and Bürgmann R 2005 The Size and Duration of the Sumatra-Andaman Earthquake from Far-Field Static Offsets; Science 308 1769-1772.

Bilham R 2005 A Flying Start, Then a Slow Slip; Science 308 1126-1127.

Curray J R 2005 Tectonics and history of the Andaman Sea Region; J. Asian Earth Sci. 25 187-232.

Dasgupta S and Mukhopadhyay M 1993 Seismicity and plate deformation below the Andaman Arc, Northeast Indian Ocean; Tectonophys. 225 529-542.

Dasgupta S and Mukhopadhyay M 1997 Aseismicity of the Andaman subduction zone and recent volcanism; J. Geol. Soc. India 49 513-521.

Dasgupta S, Mukhopadhyay M, Bhattacharya A and Jana T K 2003 The geometry of the Burmese-Andaman subducting lithosphere; J. Seismol. 7 155-174.

Dasgupta S, Mukhopadhyay B and Acharyya A 2005a Aftershock propagation characteristics during the first three hours following the 26 December 2004 SumatraAndaman Earthquake; Gondwana Res. 8 585-588.

Dasgupta S, Mukhopadhyay B and Acharyya A 2005b Seismotectonics of the Andaman-Nicobar Region: Constraints from Aftershocks within 24 Hours of the Great 26 December 2004 Earthquake; Geol. Surv. India Spec. Publ. 89 105-114.

DeShon H R, Engdahl E R, Thurber C H and Brudzinski M 2005 Constraining the boundary between the Sunda and Andaman subduction systems: Evidence from the $2002 \mathrm{Mw} 7.3$ Northern Sumatra earthquake and aftershock relocations of the 2004 and 2005 great Earthquakes; Geophys. Res. Lett. 32 L24307.

Eguchi T, Uyeda S and Maki T 1979 Seismotectonics and tectonic history of Andaman sea; Tectonophys. 57 35-51.

Gupta H 2005 Mega-Tsunami of 26th December 2004: Indian initiative for early warning system and mitigation of oceanogenic hazards; Episode 28 1-5.

Lay T, Kanamori H, Ammon C J, Nettles M, Ward S N, Aster R C, Beck S L, Bilek S L, Bredzinski R, Butler R, Deshon H R, Ekstrom G, Satake K and Sipkin S 2005 The great Sumatra-Andaman earthquake of 26 December 2004; Science 308 1127-1132.

Meredith P G, Main I G and Jones C 1990 Temporal variations in seismicity during quasi-static and dynamic rock failure; Tectonophys. 175 249-268.

Mogi K 1988 Downward migration of Seismic Activity Prior to Some Great Shallow Earthquakes in Japanese Subduction Zones - A possible Intermediate-term Precursor; $P A G E O P H \mathbf{1 2 6}$ 447-463.

Mukhopadhyay M 1984 Seismotectonics of subduction and backarc rifting under the Andaman Sea; Tectonophys. $108229-239$.

Mukhopadhyay M 1988 Gravity anomalies and deep structure of Andaman arc; Marine Geophys. Res. 9 197-210.

Scholz C H 1988 Mechanisms of Seismic Quiescences; PAGEOPH 126 701-718.

Smith W D 1986 Evidence for precursory changes in the frequency-magnitude b-value; Geophys. J. Roy. Astron. Soc. 86 815-838.

Stein S and Okal E A 2005 Speed and size of the Sumatra earthquake; Nature 434 581-582.

Vigny C, Simons W J F, Abu S, Bamphenyu R, Satirapod C, Choosakul N, Subarya C, Socquet A, Omar K, Abidin H Z and Ambrosius B A C 2005 Insight into the 2004 Sumatra-Andaman earthquake from GPS measurements in southeast Asia; Nature 436 201-206. 